\title{
Primary Source Citations
}

References to works of Rousseau appear in the text in parentheses immediately after the citations. Translations from the French editions are my own. The references use the following abbreviations.

I, 1-ooo Oeuvres complètes. Paris: Gallimard, Bibliothèque de la Pléiade, 195969 ; references are cited by volume and page numbers. Occasional references to the Geneva edition (1782-89), 33 volumes, are cited as such.

d'Alembert Letter to M. d'Alembert on the Theatre. Trans. Allan Bloom. In Politics and the Arts. Ithaca, N.Y.: Cornell University Press, Agora Editions, 1968.

Discourses The First and Second Discourses. Trans. Roger D. Masters and Judith R. Masters. New York: St. Martin's Press, 1964 .

D.M. Dictionnaire de musique. New York: Johnson Reprint Corporation, 1969 .

Emile Emile, or On Education. Trans. Allan Bloom. New York: Basic Books, 1979.

J.J. Jean-Jacques entre Socrate et Caton. Ed. Claude Pichois and René Pintard. Paris: José Corti, 1972.

S.C. On the Social Contract, with Geneva Manuscript and Political Economy. Trans. Judith R. Masters. Ed. Roger D. Masters. New York: St. Martin's Press, 1978. 

Rousseau's Exemplary Life 
